\title{
Domes of adobe and stone on the rural architecture of centre of Castilla y León (Spain)
}

\author{
O. Abril Revuelta \& F. Lasheras Merino \\ Departamento de Construcción y Tecnología Arquitectónicas, Universidad Politécnica de Madrid, España
}

\begin{abstract}
In the centre of Castilla y León (extensive zone of Spain) still there are some examples of the old rural buildings linked to the economic activities that have been developed in the agrarian field. These are called chozos and casetas, and they have been erected with domed solutions using the autochthonous materials: the mud in the region of Tierra de Campos and the stone in the region of Montes Torozos. The influence of traditional construction techniques of both elements has generated a singular typological range rarely seen in the rest of the Península Ibérica. All different types of domes found in this place will be explained from its construction process, adding its structural capacity and energy bioclimatic qualities.
\end{abstract}

\section{DOME AND ITS CONCEPT OF REFUGE IN FARMED ACTIVITY}

Castilla y León is one of the regions of the peninsula with greater historical significance, but also it has been of which better has represented the typical image of the inland of Spain, where society has deeply been linked to farmed activities.

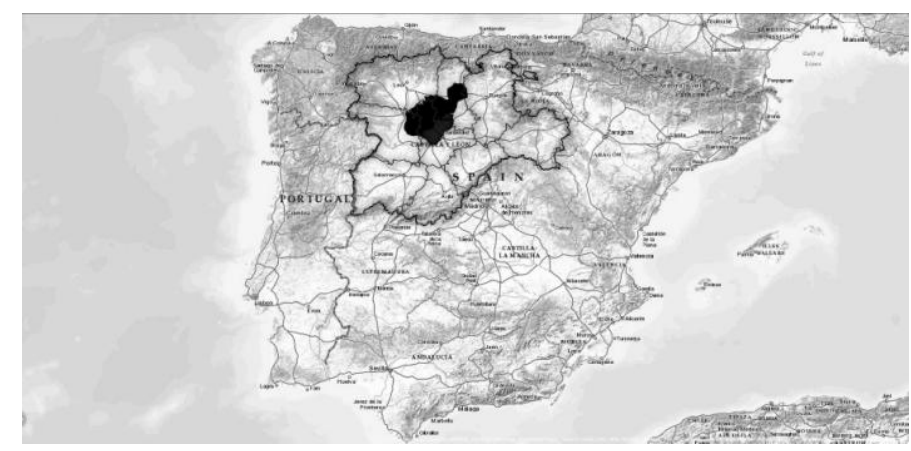

Figure 1. Geographical setting. (Abril Revuelta, O. 2013)

Agriculture and livestock have supposed jobs that entailed hard and long working days made in places far from towns. This fact motivated the farm workers lift constructions that helped in this job and where the rural men could shelter of the sun, of the cold or spend the night. These elements also served for storage of tools or to the refuge of some animal.

The covering of these small buildings has been made by vaulted solutions in many cases. The origin of this construction system has been treated and explained from different perspectives by various authors, without establishing an absolute theory. How- ever, we can say that the dome has been conceived, since ancient times, as the figure that best represents the concept of shelter, and we can check it through examples of prehistoric or primitive architecture. It is clear that domed shape is that cover that seems to give us a greater sense of refuge and protection.

\section{THE STUDY OF VAULTED SOLUTIONS IN RURAL ARCHITECTURE}

\subsection{Methodology}

Three phases of work are employed to investigate the roof of theses farmed constructions. The first is the documentary research, where it should be noted that from works of Carlos Flores (1973) and Luis Feduchi (1974) we can found more interesting studies about this vernacular architecture. However, it has been found that the buildings erected outside the towns have not been the focus in most prominent analysis of traditional constructions, as these have centred his work mainly on traditional housing. This effect is due to the enormous difficulty that has supposed the recognition of rural buildings away from small villages, especially in a so extensive region with low population density. Fortunately, and simultaneously to the imminent demise of these constructions, every time we find more specific works, not only about this vernacular architecture, but also relating to the vaulted solutions.

The second phase is the work on field, where it is necessary to have a wide knowledge of the place. For a good search of the rural buildings, in addition 
to organizing strategic itineraries, it is vital to have the collaboration of the residents of the place, as they are who know best the territory and a great source of information.

Finally, after the taking of data in situ of each element, classification and characterization of domed system are used to explain and to value a traditional technique that has practically been forgotten. And in this phase, the graphical representation is very important to describe this construction system.

\subsection{Nature environment like determining factor}

In the heart of the Castilla y León, there are two natural regions: Tierra de Campos, that is a big extensive plain of clay, and Monte Torozos, that is a wasteland with limestone. In these areas, traditional constructive techniques have been developed with the dominant materials: the mud used in the first region and the stone in the second. In addition, in both zones the absence of arboreal mass is important. So we can found in this aspect the first determining factor that justifies the use of the vaulted systems to cover these humble buildings, because it is a simple and inexpensive way to close a space, without the need to resort to other types of structural elements, as it is usually the wood for the roofs of the residential buildings.

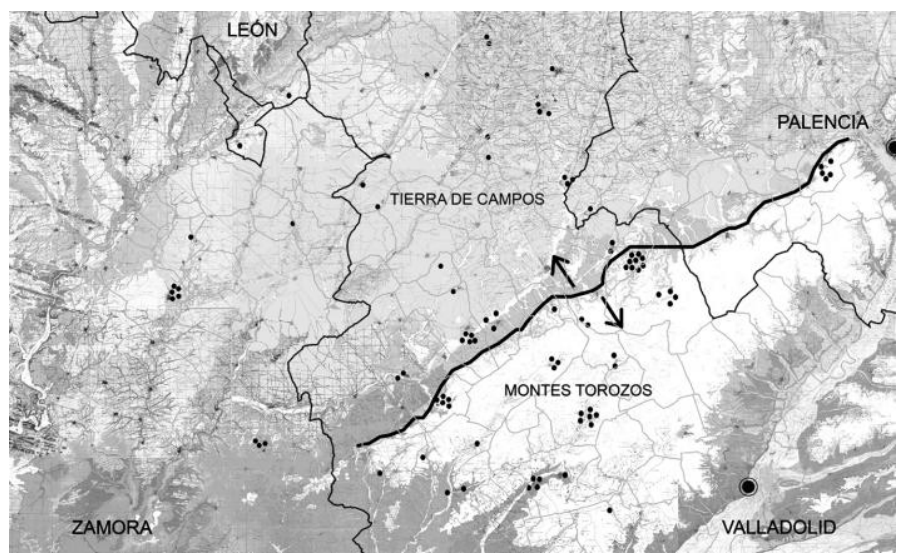

Figure 2. Geological map of Tierra de Campos and Montes Torozos. Points are cases studied. (Abril Revuelta, O. 2013)

The peculiarity of this area is the architectural influences that produce between both regions and especially in their bordering zone. So, we have observed the emergence of mixed constructions system (with elements of clay and limestone) used also in the techniques for the domed covering.

\subsection{Cultural heritage and constructive reason.}

The author of the rural architecture built with logic, using the materials are available, and following the rules learned from their ancestors. Traditional builder does not innovate, but he copies what he see near of his surroundings, even, in occasions what he observes in some high quality architecture. So we can find an evolution in the building procedures based on the influence received from constructive traditions of all the architecture that is located next to which he intends to create.

On the other hand, if we look at the corbelled dome of the humble architecture on the peninsula (Fig. 3, Vegas, Mileto \& Cristini, 2010) we can see that there are many group of stone domes by the Iberian regions, one of them is on the region of Montes Torozos. But we can find only one important density of clay vaults, and this is located in Tierra de Campos. So the vicinity between both regions can explain the emergence of mixed domes (limestone and clay) on the bordering zone, from traditional constructive influences that occur in each area.

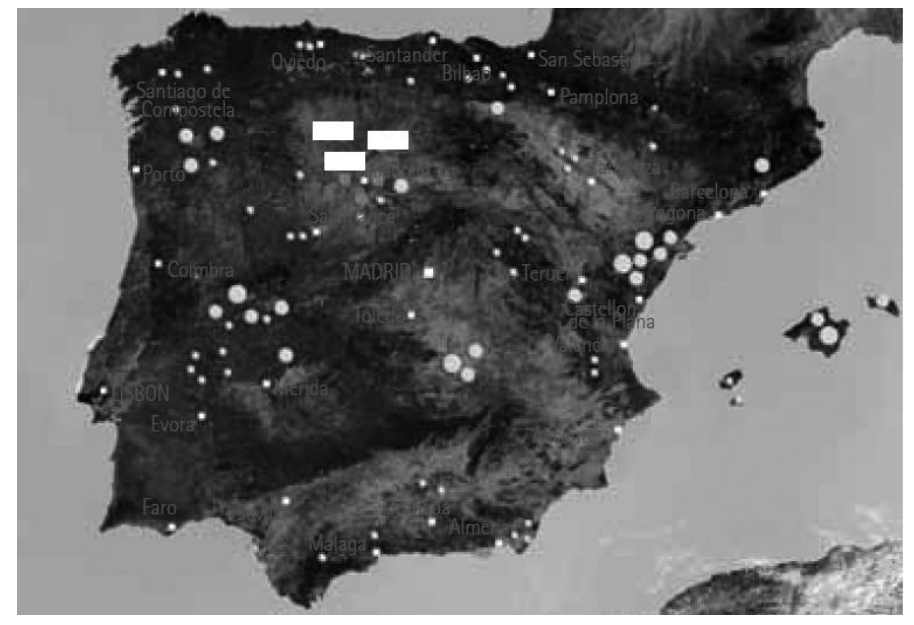

Figure 3.Coberlled domes in Spain and Portugal. Circles for the stone vaults, and rectangles for clay vaults. (Vegas, F., Mileto, C. \& Cristini, V. 2010). The map has been edited to improve its explanation.

\subsection{Construction techniques in the domes of the centre of Castilla y León}

In the development of the vaulted roofs on the agricultural buildings, the man has use small elements that he can put with their own hands, without the need to resort to mechanism for the lifting of big stones. So, the rural architects made adobe pieces or utilized limestone masonry, or, in many cases, they used both.

The domes are made using two different techniques. On the one hand we can find the system called cúpula falsa (cobelling dome), built in horizontal layers, where each piece slightly overhangs the previous. This technique is widely used in the rest of the peninsula in dry-stone constructions. On the other hand it is possible see the system cúpula auténtica (true dome), by tilting the pieces. While the first technique has seen with mud or stones, the second system has been developed only with clay, because the adobe represents a more regular format that allows better handling and disposal for the making of these real vaults. 
It is necessary to stand out that false dome tends more a pointed arch than true dome. This is because the system of horizontal layers does not allow excessive overhangs to make a perfect geometric arch. Even, in a lot of examples this technique tends to sharp figures, like cones or pyramids (if the previous floor of the constructions is square).

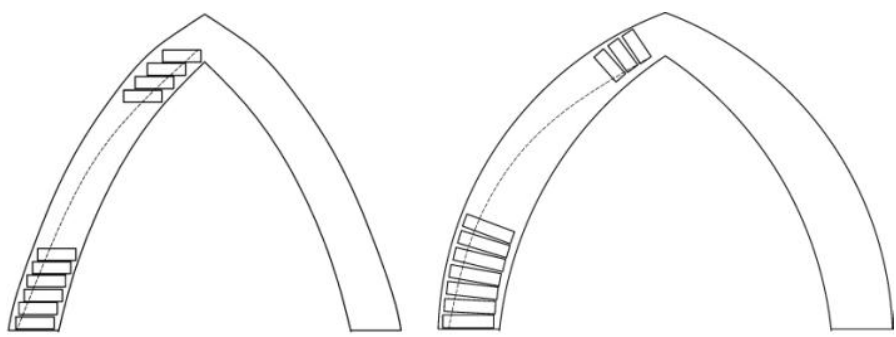

Figure 4.Vaulted system: corbelled (left) and real (right) dome. (Abril Revuelta, O. 2013)

\section{CLASIFICATION AND CHARACTERIZATION OF DOMES IN THE CENTRE OF CASTILLA Y LEÓN.}

\subsection{Classification according to the material.}

We can identify three main types of domes based on the material used, that can be arranged in different systems to get a great typological variety (Fig. 11).

\subsubsection{Clay domes.}

They are mainly in Tierra de Campos (as in next villages: Ceínos de Campos, Tamariz, Cuenca de Campos,..), but also near the hill bordering (for example the domes in Urueña), and even there are some mud vaults inside Montes Torozos (Torrelobatón), with clear differences in the earth colour, being more red in the plain zone and ochre or gray on the wasteland area.

We have observed true domes and false domes, made whit clay (Fig. 5). Always they are built with the technique of adobe. Sometimes there are some different formats within the same vault, such as some trapezoidal pieces (in dowel shape).
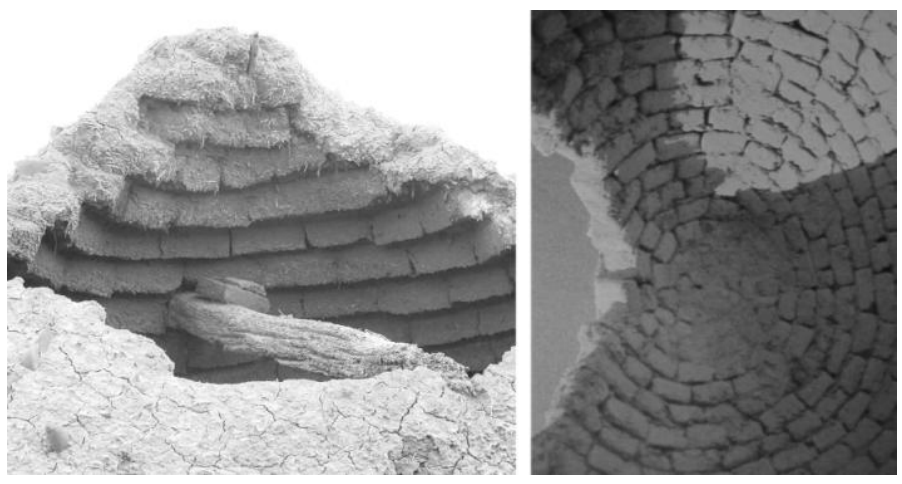

Figure 5. Some earthen domes. (Left) Becilla de Valderaduey (Valladolid) with false system (Abril Revuelta, O. 2013). (Right) Valdescorriel (Zamora), real dome (Alonso Ponga, J.L. 1989).

\subsubsection{Stone domes}

This vaults are mainly into the hill zone (as the chozos in Castromonte, in La Mudarra or in Peñaflor), but also there are some on the limit with the plain (Villabragiama or Palacios de Campos).

Usually they are resolved with the stepped system (false dome), because to make a real vault would be necessary a good work in the cutting of stone and these construction are very humble. However, it is possible to see some real dome, built by expert masons in areas with great stone tradition.

This dome, usually pointed, is resolved whit two layers or skins. The inside shell is made bringing closer each new rings to the centre of construction some few centimetres (Fig. 6), and the outside skin becomes more disjointed with more organic pieces, making a protect cover.

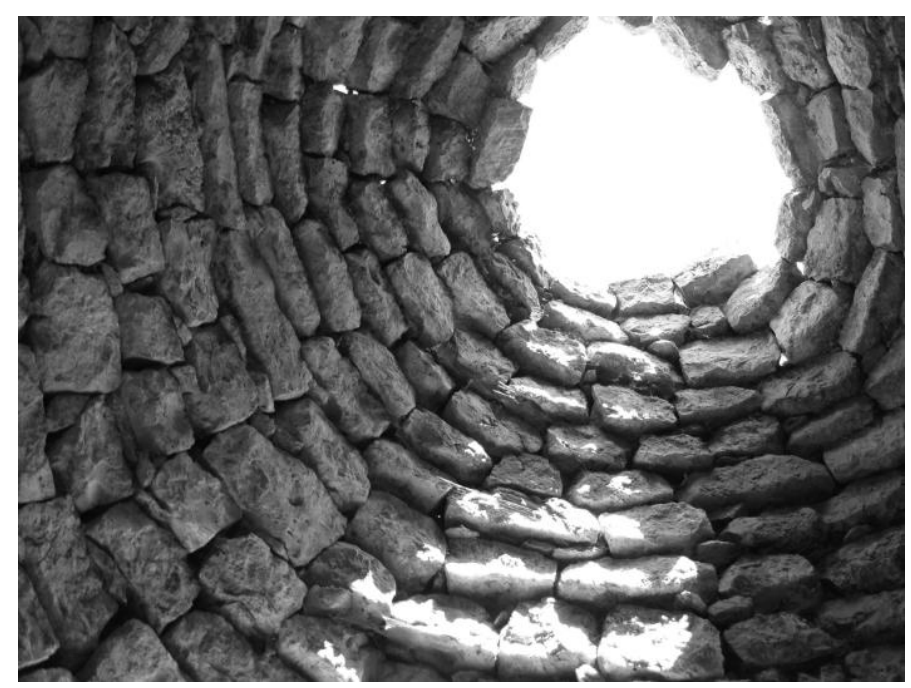

Figure 6. Stone vault in Medina de Rioseco (Valladolid). (Abril Revuelta, O. 2013).

\subsubsection{Clay and stone domes}

Often, we can find them on the bordering between the plain and the hill (Montealegre de Campos, Autilla del Pino or Villasexmir), and it is a logical effect because this space is where both materials are on hand, and therefore both constructive tends have been created. On the other hand, two types of combination clay - limestone have been detected.

The first is similar to the stone domes, where we found two skins. On this occasion, the indoor layer, made with adobes, is generated according to the chosen system (by stepped pieces or slope the adobes). The external skin serves of protection, and it is very useful to prevent erosion and disintegration of the clay shell from winding and raining (Fig. 7).

The second option, which it can also be done with two skins, consists in a start of the vault only with limestone pieces. This part is made through false system, and reaches the half dome or a little more. From this place to the culmination, the construction is built whit earth. This final part can be erected as a false vault or true dome (Fig. 8). 


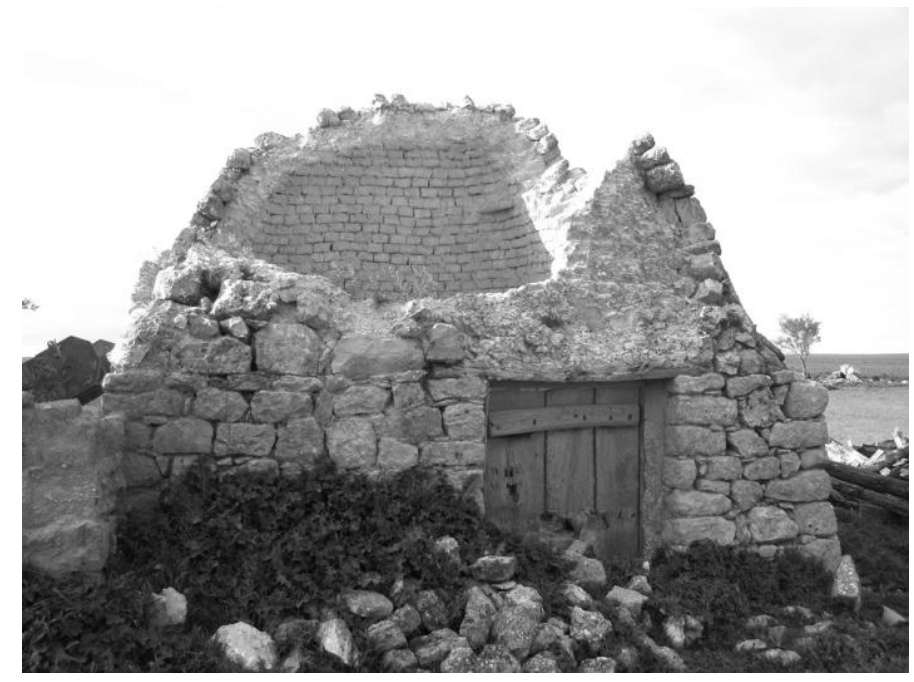

Figure 7. Chozo in Autilla del Pino (Palencia) with dome of two skins. Indoor in adobe and outdoor in limestone. (Abril Revuelta, O. 2013).
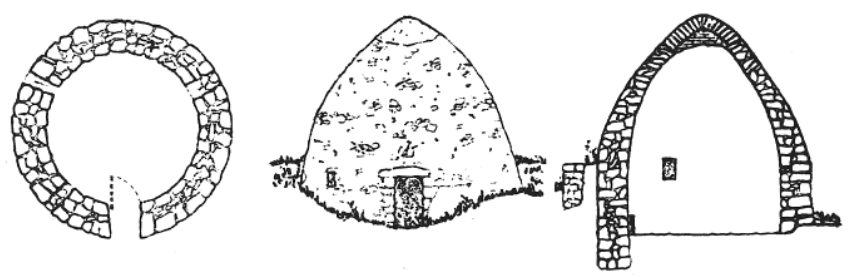

Figure 8. Chozo in San Cebrián de Mazote (Valladolid) with dome of stone (at the beginning) and mud (in the culmination). (Carricajo Carbajo, C. 2010.).

\subsection{Constructive characteristics in the built phases}

\subsubsection{Starting the dome.}

The natural birth of a dome would leave a circular floor. In many cases this vault start from a small foundation, made with little stones, which improves the stability of the construction. This foundation is sometimes extended to become a small circular base that, on the other buildings, it can form a large wall, where the dome sits.

Nevertheless a very common feature in these constructions is the rectangular or square floor, especially in Tierra de Campos, and it is probably due to the two mud techniques, rammed-earth and adobe, are orthogonal elements. However, it was curious to find into the stone area of the hill many rural buildings with stone walls making square floor, unlike that seen in the rest of the peninsula, where it is normal that the domed buildings built whit dry-stone are circular floor. We can think that some certain influences have been transmitted from mud area in this aspect.

The way to adapt this orthogonal shape to the circle for the start of the dome has been solved in several manners but following the same concept: chamfering the corners to get the octagon, figure more similar to the circle (Carricajo Carbajo, C. 2010).
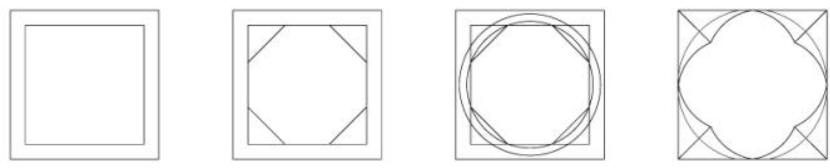

Figure 9. Geometric processes to adapt the square floor at the beginning of the dome. (Abril Revuelta, O. 2013).

However, this procedure has been performed of different ways. A very common case is to resort to several wooden beams arranged at the corners. On the other hand, near the hill we find solutions with big stones slabs situated like a cantilevered vault. Another interesting way is the creation of pendentives using adobes or small stone pieces.

Other option was the omission of the previous octagon and the make a vault with pyramidal shape that starts directly from the orthogonal plan. And this system has been made with stone, with adobe or with both elements.

\subsubsection{Crowning the top.}

It has been interesting to find flexible solutions in terms of the functionality of the building. For example in many chozos made with stone, the latest staggered rows were omitted forming an oculus that served as flue (Fig. 6). When it was raining this part was covered with a circular stone slab.

For earth buildings the solution was usually to place pieces of adobe in the last row in vertical position, as a key that closes the compression ring. This element is also seen in stone constructions using limestone pieces liked a "rugby ball" that by its indoor part has a structural function, and by its top formed a pinnacle, being an aesthetic element.

\subsection{Structural analysis of the domes}

The structure of this constructions is not a great complexity, because its size is not excessive, however the domed erection shows us great ingenuity by the vernacular architect. It is necessary to stand out to make this vaults these rural builders did not use the auxiliary structures as centring (called cimbra in Spain), because its cost would be several times what all the building. So in its building process the man used some humble tools, as compass and strings for aligning the rows, and his own expertise.
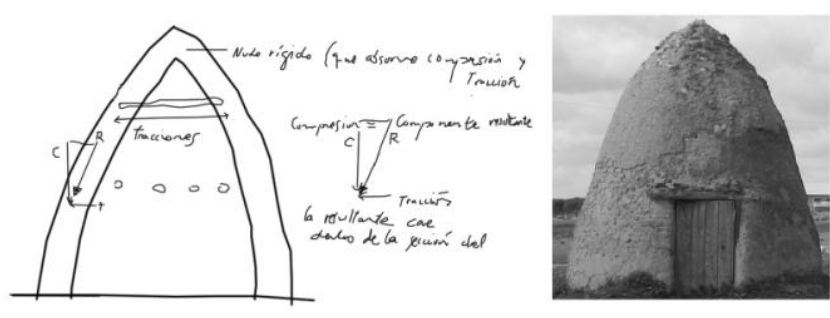

Figure 10. Sketch of structural behaviour of chozo in Torrecilla de la Abadesa (Valladolid). (Olcese Segarra, M. 1992). 


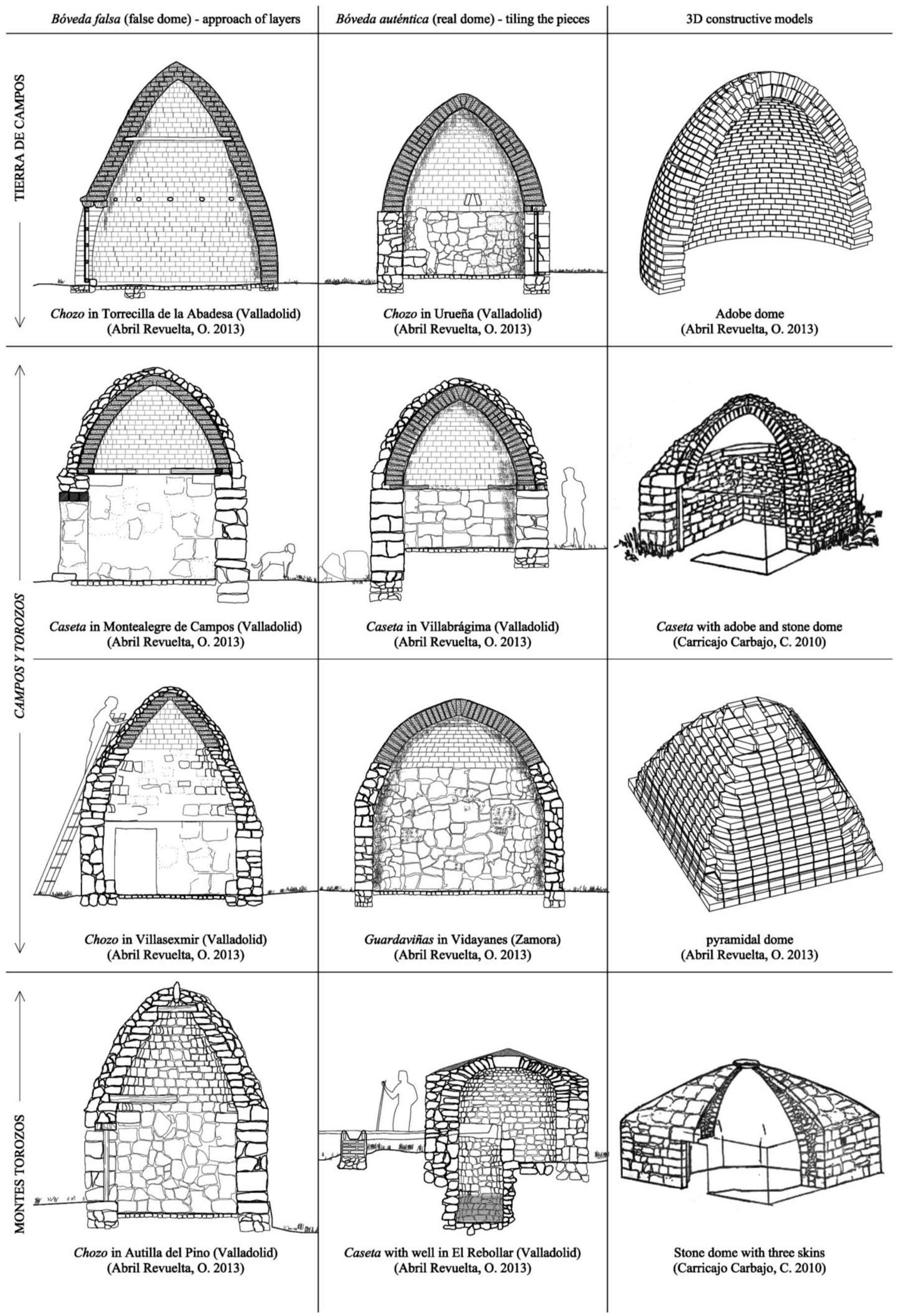

Figure 11. Typological scheme of domed buildings 
Nevertheless, in the dome each ring made is stable by itself, more in the real vaults, because there are more compressions in their pieces. The figure of these domes is formed by parabolic guidelines, which allow a better transmission of loads to the walls (Olcese Segarra, M. 1992). Even so, it is interesting discover that these rural builders incorporated some wooden beams that absorb the possible generated tractions (Fig. 10).

In addition, it must distinguish between the vaults made with earth and with stone. In clay domes there is a different concept, the adherent factor of the mud, include in the bricks and in the coating clay. This factor increases the building rigidity. This effect has led to consolidate the building almost the same mass, so its collapse is mainly by erosion and disintegration. On the other hand, in stone domes the structural failure happens by omission or falling of one or some limestone pieces.

\subsection{Bioclimatic behaviour}

Although the erection of these small building was a matter of working functionality, the reality is that many of them became elements of shelter, that should have minimum comfort conditions for the stay inside. And it is obvious that this domed enclosure helps for this purpose.

Vault can be more spherical or more parabolic, but anyway, the domed figure is the most refractory geometric envelope, distributing the heat in a very effective manner. This is explained in its volume, that is decreasing as increases the shape, causes the hot air quickly colonizes the highlands keeping the heat in the lower area by over-pressure of the upper layers (Bernalte Patón, F.J. 2004).

In addition, this figure presents the minimum surface exterior to the interior volume reducing thermal losses, compared with sloping roofs. In this way we can say that the dome is the envelope that better manages the heat and also with its double curvature is ideal to resist the cold winds in any direction.
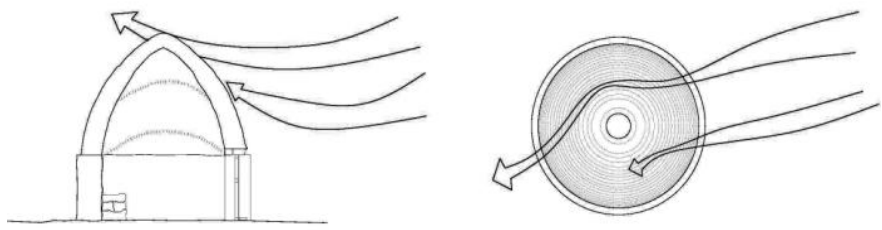

Figure 12. Sketch of wind behaviour in chozo. (Abril Revuelta, O. 2013).

Also, we can add that the covering of these buildings are made with big thicknesses that we consider structurally unnecessary, but very useful for thermal performance. Special interest exists on the mud domes, by its low conductivity, but especially for its good thermal inertia which causes an interesting phase difference, capable of giving inside the heat accumulated during the day at night.

\section{CONCLUSIONS}

First, we think that the study of a technique almost obsolete must be considered important to preserve it, at least graphically. We know of low utility that these buildings currently have for agricultural or livestock activity, causing the abandonment and neglect of these constructions of the rural heritage of Castilla y León.

On the other hand, we think that the confluence of traditional building techniques between Tierra de Campos (mud) and Montes Torozos (limestone) have created a unique mixed architecture that creates an admirable typological variety, highly expressed in the domed solutions (Fig. 11). And it is not only displayed in the formation of structures that combine earth and stone (because both material are available for rural architect, and both are inexpensive in this constructions) in their process of building, but also in the formal aspect causing stone buildings with square floor, more common in earthen architecture. This an effect rarely seen in the rest of peninsula (as Bombos in Castilla La Mancha, chozos in Extremadura or Aragón, or Barracas in Cataluña). We can conclude that it is a singular architecture.

Finally, we reflect on the great architectural qualities that exist in traditional buildings, where we can check that with logic and common sense can be erected safe, functional and very beautiful buildings. And these qualities should see more in contemporary architecture.

\section{REFERENCIES}

Alonso Ponga, J.L. 1989. La arquitectura del barro. Valladolid: Junta de Castilla y León

Bernalte Patón, F.J. 2004. Bombos de Tomolloso: la cúpula como vivienda. Tesis doctoral no publicada. Universidad Politécnica de Madrid.

Carricajo Carbajo, C. 2010. 50+1 Construcciones vernácula en la provincia de Valladolid. Valladolid: Diputación de Valladolid

Feduchi, L. 1974. Itinerarios de la arquitectura popular espanola. Barcelona: Blume.

Flores C. 1973. Arquitectura popular española, tomo 3. Madrid: Aguilar.

Olcese Segarra, M. 1993. Arquitecturas de tierra: tapial y adobe. Valladolid: Colegio Oficial de Arquitectos en Valladolid.

Vegas, F. Mileto, C \& Cristini, V. 2010. Corbelling Domes and Bridges in Spain and Portugal: a comparative study. VI International Conference on Arch Bridges. Fuzhou, Fujian, China. 